\title{
IbM USAHA PEMBERDAYAAN GURU - GURU SECARA FISIK MELALUI PROGRAM PELATIHAN SENAM BUGAR DI SMK NEGERI 1 RATAHAN
}

\author{
Tony Pandaleke \\ Program Studi Pendidikan Jasmani, Kesehatan, dan Rekreasi, Fakultas Ilmu Keolahragaan, \\ Universitas Negeri Manado (UNIMA)
}

\begin{abstract}
Abstrak
Pemberdayaan merupakan usaha untuk memberi daya atau kekuatan agar guru - guru memiliki kemandirian terutama dalam aspek fisik, maka perlu diberdayakan fisiknya dengan cara meningkatkan kebugaran jasmani. Kebugaran dipandang dari aspek fisiologis adalah kebugaran total (total fitness) yang memberi kesanggupan atau kemampuan kepada seseorang untuk menjalankan hidup produktif dan dapat menyesuaikan diri dengan pembebanan (stress) fisik yang layak. Pemberdayaan tidak hanya masalah pembangkitan kesadaran, tetapi juga upaya mengubah keadaan kehidupan material orang-orang yang tertindas dan lemah dalam masyarakat. Salah satu mitra untuk melakukan kegiatan pengabdian bagi masyarakat dalam upaya peningkatan kualitas fisik guru - guru, tim pengabdi mengambil mitra guru - guru SMK Negeri 1 Ratahan Kabupaten Minahasa Tenggara. Permasalahan mitra yaitu kesibukan dalam mengajar di dalam kelas membuat guru - guru terlalu sibuk dan melupakan diri untuk tetap berolahraga agar tubuh tetap bugar. Belum mengetahui dan memahami bagaimana teknik membantu diri untuk tetap bugar dan dapat menjalankan tugas baik sebagai guru ataupu orangtua di rumah dan guru-guru belum pernah mendapatkan pelatihan sebagai upaya pemberdayaan dalam bentuk senam bugar serta membentuk pusat pelatihan kebugaran sendiri di sekolah maupun di rumah dan di lingkungan sekitar. Dampak yang didapat adalah seluruh guru - guru tersebut mereka menjadi bugar, sehingga bisa hidup mandiri, tidak mudah sakit, yang berdampak pula pada faktor ekonomis dan psikis.
\end{abstract}

Kata Kunci: Pemberdayaan, Guru-guru, Senam bugar.

\section{PENDAHULUAN}

\section{Analisis Situasi}

Pemberdayaan merupakan usaha untuk memberi daya atau kekuatan agar guruguru memiliki kemandirian terutama dalam aspek fisik, maka perlu diberdayakan fisiknya dengan cara meningkatkan kebugaran jasmani. Kebugaran dipandang dari aspek fisiologis adalah kebugaran total (total fitness) yang memberi kesanggupan atau kemampuan kepada seseorang untuk menjalankan hidup produktif dan dapat menyesuaikan diri dengan pembebanan (stress) fisik yang layak. Bentuk atau wujud dari upaya tersebut di atas akan bermakna dan bermanfaat bagi diri guru - guru tersebut dan keluarga. Apabila kebugaran jasmani guru - guru terjaga, maka guru - guru akan memiliki kemandirian, tidak hanya aspek fisik saja, melainkan menyangkut aspek yang lain yaitu psikis sosial dan ekonomis, sehingga ketergantungan kepada anak cucunya menjadi berkurang.

Pemberdayaan tidak hanya masalah pembangkitan kesadaran, tetapi juga upaya mengubah keadaan kehidupan material orang-orang yang tertindas dan lemah dalam masyarakat. Kajian teori yang berhubungan dengan pemberdayaan dan lanjut usia (menurut Mas'ud 1993) upaya untuk 
memperkuat posisi seseorang melalui penumbuhan kesadaran dan kemampuan individu. Untuk mengidentifikasi persoalan yang dihadapi dan memikirkan langkahlangkah untuk mengatasinya. Menurut Tjandraningsih (1995), merupakan suatu proses perubahan dari ketergantungan kepada kemandirian, melalui perwujudan kemampuan yang dimiliki. Menurut Sumodiningrat (1996), usaha pemberdayaan didasari filsafat tentang akan hak dan kewajiban manusia, serta adanya anggapan bahwa manusia mempunyai potensi atau kemampuan daya yang dapat dikembangkan.

Guru adalah jabatan atau profesi yang membutuhkan keahlian khusus. Pekerjaan sebagai guru ini tidak bisa dilakukan oleh seseorang tanpa mempunyai keahlian sebagai guru. Menjadi seorang guru dibutuhkan syarat-syarat khusus. Apa lagi jika menjadi seorang guru yang profesional maka harus menguasai seluk beluk pendidikan serta mengajar dengan berbagai ilmu pengetahuan lainnya yang harus dikembangkan melalui masa pendidikan tertentu. Di dalam pendidikan, guru mempunyai tiga tugas pokok yang bisa dilaksanakan yaitu tugas profesional, tugas kemasyarakatan dan tugas manusiawi. Tugas profesional adalah tugas yang berhubungan dengan profesinya. Tugas profesional ini meliputi tugas untuk mendidik, untuk mengajar dan tugas untuk melatih. Mendidik mempunyai arti untuk meneruskan dan mengembangkan nilai-nilai hidup. Mengajar mempunyai arti untuk menerus- kan dan mengembangkan ilmu pengetahuan serta teknologi, dan tugas melatih mempunyai arti untuk mengembangkan keterampilan. Tugas manusiawi merupakan tugas sebagai seorang manusia. Guru harus bisa menjadikan dirinya sebagai orang tua kedua bagi murid. Guru harus bisa menarik simpatik sehingga dia menjadi idola bagi siswa. Selain itu transformasi diri terhadap kenyataan di kelas atau di masyarakat harus dibiasakan agar setiap lapisan masyarakat bisa mengerti jika menghadapi guru.

Salah satu mitra untuk melakukan kegiatan pengabdian bagi masyarakat dalam upaya peningkatan kualitas fisik guru-guru, tim pengabdi mengambil mitra guru-guru SMK Negeri 1 Ratahan Kabupaten Minahasa Tenggara. Dampak yang nantinya didapat adalah seluruh guru-guru tersebut mereka menjadi bugar, sehingga bisa hidup mandiri, tidak mudah sakit, yang berdampak pula pada faktor ekonomis dan psikis. Dalam hal proses pendidikan dan latihan atau pelatihan, interaksi antara instruktur dan peserta menjadi penentu efektifitas pelaksanaan program. Sehingga diperlukan Instruktur Senam guru-guru Bugar yang baik dan profesional, agar proses pelaksanaan pelatihan bisa berjalan secara efektif. Peserta pelatihan dalam proses pelaksanaan pelatihan merupakan sasaran utama dalam pelatihan. Keberhasilan dalam pelaksanaan dapat diukur dari kemajuan peserta pelatihan baik secara afektif, kognitif dan psycomotorik. Dukungan pengelola dalam pelaksanaan 
pelatihan baik sebelum, selama dalam proses pelaksanaan dan setelah pelatihan juga harus memperhatikan kebutuhan sarana dan prasarana (termasuk media) ini dirancang sesuai dengan jenis pelatihannya. Pelatihan senam guru-guru bugar meliputi gedung beserta peralatannya. Sarana dan prasarana yang tepat akan mendorong peserta pelatihan lebih bersemangat dalam berlatih.

Melalui kegiatan pengabdian ini dalam bentuk program pelatihan senam guru-guru bugar diharapkan para guru-guru akan lebih bugar secara fisiknnya sehingga akan memberi harapan hidup lebih lama, dan apabila guru-guru bugar tidak akan merepotkan keluarganya serta dalam hubungannya dengan kesehatan, guru-guru akan lebih ekonomis dalam pemeliharaan kesehatannya. Dalam pelaksanaannya agar efektif tim pengabdi memprogramkan cara dengan memberi pelatihan kepada guru - guru di SMK Negeri 1 Ratahan. Dan diharapkan bisa memasyarakatkan senam guru - guru bugar ini kepada lingkungannya. Senam guru-guru bugar adalah suatu bentuk senam kebugaran yang diperuntukkan para guru-guru) sehingga bentuk kegiatan latihannya disesuaikan dengan orang lanjut usia, maka dari itu tim pengabdi mencarikan Instruktur senam guru-guru bugar yang sesuai atau memahami betul akan senam guru-guru bugar.

\section{Permasalahan Mitra}

Berdasarkan latar belakang yang telah dijelaskan di atas, permasalahan mitra usaha dalam hal ini guru-guru sebagai motor penggerak keberlanjutan pendidikan yang mewadahi permasalahan mitra usaha yaitu:

1. Kesibukan dalam mengajar di dalam kelas membuat guru-guru terlalu sibuk dan melupakan diri untuk tetap berolahraga agar tubuh tetap bugar;

2. Belum mengetahui dan memahami bagaimana teknik membantu diri untuk tetap bugar dan dapat menjalankan tugas baik sebagai guru ataupu orangtua di rumah;

3. Guru-guru belum pernah mendapatkan pelatihan sebagai upaya pemberdayaan dalam bentuk senam bugar; dan

4. Membentuk pusat pelatihan kebugaran sendiri di sekolah maupun di rumah dan di lingkungan sekitar.

\section{TARGET DAN LUARAN}

\section{Target Pelaksanaan}

Pelaksanaan kegiatan PPM ini memiliki target, yaitu:

1. Menciptakan sumber daya manusia (SDM) yang bisa mandiri menjadi instruktur senam guru - guru bugar;

2. Instruktur hasil pelatihan, bisa melatih senam guru - guru bugar didaerahnya; dan

3. Para guru - guru yang ada didaerah bisa meningkat kebugaran jasmaninya. 


\section{Luaran Pelaksanaan}

1. Bagi peserta akan menambah wawasannya dalam hal jenis senam yang bisa meningkatkan kesegaran jasmaninya;

2. Bagi Instansi atau Lembaga tempat PPM akan memiliki Sumber Daya Manusia (SDM) yang lebih berkualitas dibidang pelatihan Senam Guru-guru Bugar; dan

3. Bagi penyelenggara, bisa mengamalkan salah satu dari Tri Dharma Perguruan Tinggi yaitu Pengabdian Kepada Masyarakat.

\section{METODE PELAKSANAAN}

\section{Kerangka Pemecahan Masalah}

Masalah yang perlu mendapat perhatian adalah kondisi fisik guru-guru yang berada di Kabupaten Minahasa Tenggara pada umumnya dan guru-guru SMK N 1 Ratahan pada khususnya. Strategi yang ditempuh adalah dengan cara memberi pelatihan senam guru-guru bugar. Diharapkan para guru-guru dalam hal kebugaran jasmaninya akan meningkat setelah melaksanakan senam guru-guru bugar dalam seminggu minimal 3 kali.

\section{Tahapan Evaluasi Kegiatan}

1. Metode ceramah: untuk menjelaskan tentang materi yang akan diberikan yaitu mengenai senam guru-guru bugar beserta manfaatnya baik secara fisik, psikis dan ekonomis;
2. Metode Demonstrasi: mendemonstrasikan gerakan gerakan senam guru-guru bugar, yang diikuti oleh peserta;

3. Metode Komando: untuk memberi komando atau aba-aba dalam pelaksanaan pelatihan senam guru-guru bugar; dan

4. Metode Resiprokal: metode dengan ciri ada pelaku dan pengamatnya, sehingga peserta bisa saling melakukan dan saling menilai terhadap temannya.

\section{Tahapan Evaluasi Kegiatan}

Evaluasi dilakukan segera setelah proses pelaksanaan pelatihan selesai. Adapun instrumen-instrumen yang akan digunakan untuk mengukur tingkat keberhasilan kegiatan yang dilakukan adalah:

1. Instrumen evaluasi instruktur senam guru-guru bugar oleh peserta;

2. Instrumen evaluasi peserta pelatihan senam guru-guru bugar oleh peserta;

3. Instrumen pengelola oleh peserta; dan

4. Instrumen sarana dan prasarana oleh peserta.

\section{HASIL DAN PEMBAHASAN}

\section{Deskripsi Hasil Kegiatan}

Kegiatan pengabdian kepada masyarakat dapat dilaksanakan sesuai dengan rencana, yakni pada Hari Jumat, 21 Juli 2017. Kegiatan diawali oleh laporan ketua tim kepada Kepala Sekolah SMK N 1 Ratahan. Narasumber pada kegiatan ini adalah: 1) Drs. Tony Pandaleke/Ketua Tim. Peserta 
yang terlibat dalam kegiatan ini sebanyak 152 orang dari guru - guru, staf dan siswa siswi SMK N 1 Ratahan.

Adapun tahapan-tahapan yang dilaksanakan dalam kegiatan ini adalah sebagai berikut:

1. Tim bersama para instruktur bertemu dengan Kepala Sekolah SMK N 1 Ratahan

2. Setelah melapor dilanjutkan dengan ibadah bersama antara tim dan seluruh staf guru dan siswa yang sedianya selalu dilaksanakan pada setiap hari jumat.

3. Penyajian materi disampaikan oleh narasumber / instruktur yang bertujuan untuk memperkenalkan terlebih dahulu gerakan gerakan awal dari senam bugar yang akan dilaksanakan.

4. Setelah selesai memperkenalkan gerakan awal selanjutnya dilanjutkan dengan senam bugar yang langsung dapat diikuti oleh peserta.

5. Acara kemudian dilanjutkan dengan foto bersama tim pelaksana pengabdian kepada masyarakat bersama instruktur dan peserta.

6. Acara ditutup oleh ketua ketua panitia.

Selama kegiatan, peserta terlihat sangat antusias mengikuti kegiatan. Hal ini terbukti dari peserta yang meminta untuk mengulang ulang kegiatan secara berturutturut.

\section{KESIMPULAN}

Pada saat kegiatan pendampingan yang dilakukan guru - guru dan siswa sudah dapat melaksanakan senambugar tanpa instruktur lagi. Setelah pelaksanaan kegiatan selesai, kepala sekolah menyampaikan agar senam bugar ini dilaksanakan setiap hari jumat.

\section{KEPUSTAKAAN}

Fox El, Kirby TE, Fox AR (1997). Basic of Fitness, New York ; Mac Millan Publishing Company

Mas'ud Mochtar (1993), Ekonomi Politik, Pembangunan dan Pemberdayaan Rakyat, Yogyakarta, PPSK Yogyakarta

Sunarto (1978), Nilai Anak bagi Masyarakat Desa, Laporan Penelitian, Yogyakarta, FKIS IKIP Yogyakarta.

Kemenpora (2007), Senam Guru - guru Bugar, Jakarta, Dinas Olahraga dan Pendidikan Prov.DKI Jakarta.

Soekidjo Notoatmojo (1992), Pengembangan Sumber Daya Manusia, Rineka Cipta.Yogyakarta.

Suhantoro (1986), Kesegaran Jasmani, Jakarta. Dinas Kesehatan RI.

Heiden Donald, F.Murray, ten Kien and Award (1986). Employee Health and Fitness Program, Uniqee Begestion : Johper.

Tjandraningsih I(1995). Pemberdayaan AnakMengenai Pendampingan Anak. Bandung, Yayasan AKATIGA.

Sumodiningrat, Gunawan (1996), Pembangunan Daerah dan Pemberdayaan Masyarakat. Jakarta, Bina Reka Pariwara.

Prawirohusodo, Soejono (1991), Perubahan Psikuatik dan Neurologik pada Lanjut Usia, Makalah Yogyakarta, Fakultas Kedokteran UGM. 
Jurnal ABDIMAS, Vol. 11, No. 2, Agustus 2018

ISSN: 1979-0953 | e-ISSN: 2598-6066

Suardiman, Siti Partini (1995), Psikologi Perkembangan, Yogyakarta, FIP IKIP Yogyakarta. 